\title{
The Potentials of Malay Folklore In West Kalimantan on Learning Writing Short Stories
}

\author{
$1^{\text {st }}$ Fitriani $i^{1,2}, 2^{\text {nd }}$ Andoyo Sastromiharjo ${ }^{1}, 3^{\text {rd }}$ Yeti Mulyati $^{1}, 4^{\text {th }}$ Sumiyadi ${ }^{1}$ \\ \{fitrianiyahya73@gmail.com ${ }^{1}$, andoyo@upi.edu ${ }^{2}$, yetimulyati@upi.edu ${ }^{3}$, sumiati@upi.edu ${ }^{4}$ \} \\ Indonesian Language Education, Universitas Pendidikan Indonesia,Bandung, Indonesia ${ }^{1}$, \\ Indonesian Language Education, IKIP-PGRI Pontianak, Pontianak, Indonesia ${ }^{2}$.
}

\begin{abstract}
The objection of this study is to describe the achievement of student competency in writing skill on Malay folklore short stories as local wisdom in West Kalimantan. The data were observed descriptive qualitative by interview and observation from 64 teachers and students on grade XII class senior high school. The problem in this study is most of students less optimal in writing short stories skill and less understand in writing guidance. Base on preliminary study were found that students have lack ability to analyze main material and to create short story. The lack of student enthusiasm base on story which heard and discussed was known from less of vocabulary in a paragraph. This study empowering Malay folklore as a local wisdom in West Kalimantan as an approached to build and optimize the student enthusiasm in short story writing base on the right guidance.
\end{abstract}

Keywords: Folklore, writing competency, writing study

\section{Introduction}

One of the activities in Indonesian high school teaching material that plays an important role in teaching writing. Writing is one of the language competencies that exist in every level of education, from preschool to college level. Writing skills are an activity of delivering mes sages (communication) using written language as a tool or medium [11]. Based on this concept, it can be interpreted that writing is an indirect communication in the form of transferring thoughts or feelings by utilizing graphology, language structure, vocabulary, and symbols. Writing is a creative process of moving ideas into language symbols. With the activity of writing someone can pour the intentions or results of his thoughts about something, no exception as a channel of creativity. The resulting writing can be in the form of journals, scientific papers, or in the form of literature such as prose in the form of short stories, novels, and poetry [8].

Short story writing learning must be learned by high school students in class XI. This is evidenced by the announcement of the material to update the short stories in the 2013 Curriculum published teaching materials with Core Competencies KI 1: Students support and live the teachings of their religion. CC 2: Students believe and live honestly, responsibility, care (mutual cooperation), polite, confident in social relations, and nature in relationships and conversation. CC 3: Students understand knowledge (factual, conceptual, and procedural) based on curiosity about science, technology, art, cultural-related phenomena, and visible events. CC 4: Students try, process, and present in the realm of concrete (using, describing, composing, composing, and making) and abstract domains (writing, reading, calculating, drawing, and composing). Basic Competence 3.9: Analyzing the elements of short story builders in the short storybook collection and Bas ic Competency 4.9 Constructing short stories by paying attention to the building elements of the building elements.

The approach to be used in the 2013 Curriculumis text-based. A text-based approach means that students are required to be able to master the structure of the text. In addition, students are required to be able to write the text they learn. The text contained in the 2013 curriculum is in the form of literary and non-literary texts. Literary texts contained in the 2013 Curriculum are short story texts (short stories). Short story texts are studied by second-semester high schoolstudents in 
the second semester. There are four basic competencies that students must master in understanding a text, especially a short story. One of the basic competencies related to the short story text is the competence to construct the short story text. The basic competence requires students to be able to produce a product or work in the form of short stories which means students can write short stories.

Based on the results of observations that have been carried out that the abilities and interests of students in writing short stories are still lacking. Students still have difficulty determining the elements contained in short stories and reconstructing short story texts and producing a product or work. The results of interviews with Indonesian language teachers have never included local wisdomin learning to write short stories. For this reason, the writer is interested in conducting research related to the potential of local wisdom in short story writing learning.

Local wis domis a form of dialectic between humans and the knowledge of life. Knowled ge taken from human life is then reflected to help humans interpret life. As a guideline for the community, then local wis domprovides clear guidance in terms of areas that can be reached by human behavior. In the process of formation, local wisdomis not conceptualized individually but requires a communal role, namely the community. Furthermore, local wis dombecomes part of the culture and then becomes the identity and even the character of a community. Therefore, local wisdom and culture is the relationship between children and their parents. Local wisdom is nothing but a part of the culture. Cultural values are abstract layers and broad scope. This level is the ideas that conceptualize the most valuable things in people's lives. A cultural value system consists of conceptions that live in the minds of most citizens of the things they must consider valuable in life [3].

A cultural value systemus ually functions as the highest guideline for human behavior. Other human behavior systems that have more concrete levels, such as specific rules, laws, and norms, are all guided by that cultural value. Cultural values that can encourage development, including the nature of suffering, suffering, trying hard, tolerant of the attitude or beliefs of others, and mutual cooperation. Literature has a very clos ecultural relationship. Literally, it can be unders tood as a tool to direct, teach, give instructions, and good instructions. while culture is the whole of human activity, including knowledge, beliefs, morals, laws, customs, ethnicity, and other habits acquired by learning, including thoughts and behavior [13]. So, literature and culture share the same area, human activities, but in different ways, literature through the ability of imagination and creativity as the emotional ability of the author, whereas culture has more ability to reas on, as intellectual ability. three, namely imaginary epis odes, in this case, students have been trained to understand the context of the story. And the fourth, namely original writing, the instructor gives selected themes . The theme is taken fromthe results of discussions that have been conducted. The theme chosen is als o related to the experience of the students themselves, in learning to write, students strive to develop their ideas so as to create creativity in themselves. Culture to cultivate nature through writing, building a new world as 'world in words', the results are types of literary works, such as poetry, novels, drama, folklore, and so on. Thus, literature is an integral part of a culture that contains various personality-forming elements of the nation's mentality, such literature is often called ethnic literature, regional literature, or local-style literature.

Local wis domis part of the culture in the community. The ideas to be raised can originate from the localculture. Folklore is one of the literary works as a cultural treasure that has a lot of character values. In general, folklore is only oral and is passed down from generation to generation. The development of folklore which is an oral tradition turns into a written tradition. Local wisdomis part of the culture of a society that cannotbe separated from the language of the people themselves. Local wisdom is in folklore, proverbs, and folk games. Local wisdom as knowledge is found by certain localcommunities through a collection of experiences in trying and integrated with cultural understanding and the natural s tate of a place [6]. In this study, res earchers focused on local wis dom in folklore.

Writing can mean a language skill that is used to communicate indirectly, not face to face with others. W riting skills are not obtained naturally, but must gothrough the process of learning and practicing [12]. Creative writing arises from within people who have the ability to think creatively, so that the ability to write creatively and think creatively is strongly interrelated [14]. In writing a short story creative ideas are needed. 
Short stories is one of a variety of literature, because it refers to the diversity of types of written works, in addition to serialized stories, poems, novels, fiction, and similar things. The term variety is distinguished from "genre" which is usually interpreted as a "form" of literature, such as prose, poetry, and drama [5]. Short stories are fictional stories in the formof prose that are concise, with elements of the story centered on one main event so that the number and development of actors are limited, and the whole story gives a single impression. The main characteristics of a short story in terms of external structure can be identified in the form of a short and solid form, while in terms of the structure of the inside can be recognized that the story centers on one main conflict. These two main features of short stories can provideopportunities for the variety of short stories thems elves to capture and uncover various events in human life. Short stories are short stories that are intended to give a single dominant impression, and which are centered on one character in one situation and at one time [4].

Local wis dom is a manifestation of a culture that occurs with reinforcement in his life as a form of humanization in culture. This means that as a manifes tation of humanity, local wis dom is considered good so that it experiences continual reinforcement. One cultural representation that contains local wis domvalues is also in the form of literary works. So, literature can be said as part of a culture that grows and develops during society as a result of the imagination of the creator and reflection on the social phenomena that occur around it [7].

Local wis domis stored values and cultural norms that can be used as rules or guidelines for a community. Local wis domcan be clas sified based on its types, including the follo wing. a) welfare; b) hard work; c) dis cipline; d) education; e) health; f) mutual cooperation; g) gender management; h) cultural preservation and creativity; i) care about the environment; j) peace; k) politeness; 1 ) honesty; m) social solidarity; $n$ ) harmony and peace; o) commitment; $p$ ) positive thoughts; and q) gratitude [9]. The value of local wisdom generally refers to the morality of humanity which becomes a way of life, especially forSundanese people. This value refers to human morals with God, human morals with otherhuman beings, human morals towards personalities, human morals with respect to time and human morals in teaching physical and inner satisfaction

Folklore is a term from the nineteenth century to designate traditional oral stories and the sayings of European farmers and then needed to cover the oral traditions found in all societies [2].

Folklore is a story that is delivered orally in the form of prose language. Folklore can be classified into three types namely myths, legends, and folktales [1]. Folklore is a story that is s pread orally that is spread through word of mouth by the local language. This story is spread in a relatively fixed form and it is unknown who is the author [10].

\section{Methodology}

This res earch was conducted with a qualitative approach overall res earch activities directed at the potential of local wisdom in learning to write short stories. The data collection is done by document study, observation, interview. Observation sheets of student and teacher activities in learning are used as guidelines for observing student activities for time limits set during the learning process. Observations are made fromthe beginning of learning until the teacher closes the learning.

The object of local wis domis focused in the area of Kubu Raya Regency, West Kalimantan. As for the aspects of learning, samples from SMA Negeri 1 Kubu Raya, SMA Negeri 2 Kubu Raya and SMA Negeri 3 Kubu Raya are used. The schools were chosen with consideration of school variations based on the orientation of the community's interests, community interests, community facilities, climate and school culture.

\section{Results and Discussion}

Local wisdom in the form of folklore has the potential to be used in short story writing learning. In this study, researchers raised the folklore Malay West Kalimantan. Types of West Kalimantan Malay folklore consist of fairy tales, legends and myths for example Stone Crying, Batu Balah, Bujang Beji, Origins of the Wire River, Origins of the Ruay Bird. 
In-depth interview and obervasiactivities are directed at the revelation of local wisdom that has the potential for development while at the same time improving the quality of students' short story writing learning. Folklore has many values including moral values, religious values, and educational values which can all shape the character of students.

The results of interviews with Indonesian teachers related to the views / opinions of teachers about the potential of local wisdom in the form of folklore in the context of its usefulness in learning. Teachers generally have the same understanding as the use of local wis dom will make a positive contribution. Based on this reality, the form of local wis dom that has the potential to improve the quality of short story writing obtained the following main picture:(1) infomation is in understanding that the appropriate and creative use of local wisdom will be able to contribute to learning innovation and (2) the form/ ty pes of local wisdom that have the potential in learning to write short stories include objects and non objects.

\section{Conclusion}

The form of local wis domin the form of folklore has the potential for development as well as meaningfully improving the quality of learning to write short stories. Proper and creative use of folklore will be able to contribute to learning innovation. Forms of folklore that have the potential for increased learning to write short stories include fairy tales, legends, and myths that have character values.

A note as a recommendation is that this research is an exploratory effort to be able to occupy and utilize local wis domin folklore to improve learning to write short stories. The main thing to emphasize is the attention to the creative competence of teachers and students in processing and utilizing folklore.

\section{References}

[1] Danandjaja, J. (1997). Folklor Indonesia: Ilmu Gosip, Dongeng, dan lain lain (5 ed.). Jakarta: PT Pustaka Utama Grafiti.

[2] Haviland, W. A. (1993). Antropologi. Jakarta : Erlangga.

[3] Koentjaraningrat. (1984). Manusia dan Kebudayaan di Indonesia. Jakarta: Djambatan.

[4] Nuryatin, A.(1989). Cerita Pendek sebagai Bahan Apresiasi dan Ajang Penulisan Kreatif Siswa Sekolah Menengah. Semarang: Pembinaan Bahasa Indonesia.

[5] Oemarjati, B. S. (1991). "Pembinaan Apresiasi Sastra dalam Proses Belajar-Mengajar". Bulir-Bulir Sastra dan Bahasa: Pembaharuan Pengajaran. (B. K. Purwo, Ed.) Yogyakarta: Kanisius.

[6] Padmanugraha, A. S. (2010). Common Sense Outlook on Local Wisdom and Identity: A Contemporary Javanese Natives Experience. Yogyakarta: International Conference on "Local Wisdom for Character Building".

[7] Sartini. (2004). Menggali Kearifan Lokal Nus antara: Sebuah Kajian Fils afati. Jurnal filsafat, 111-120.

[8] Semi, M. A. (1995). Dasar-dasar keterampilan menulis. Bandung: Mugantara.

[9] Sibarani, R. (2012). Kearifan Lokal, Hakikat, Peran, dan Metode Tradisi Lisan: Asosiasi Tradisi Lisan.

[10] Sukamto. (1992). Jurnal Penelitian: Cerita Rakyat Daya Taman. Pontianak: Universitas Tanjung Pura.

[11] Suparno, \& Yunus, M.(2009). Keterampilan Dasar Menulis. Jakarta: Universitas Terbuka.

[12] Tarigan, H. G. (1986). Prinsip-Prinsip Dasar Sastra. Bandung: Angkasa.

[13] Trianto, A. (2008). Perkawinan Adat Wologoro Suku Tengger. Jakarta: Prestasi Pustaka.

[14] Wardhana, W. A., \& Ardianto, A. S. (2007). Menyikapi Rahasia Jadi Penulis. Yogyakarta: Pustaka Pelajar. 